Article

\title{
The Structure of Change: A Structural Interpretation of the Biblical Story of Joseph
}

\author{
Samuel Cooper and Shlomo Guzmen-Carmeli * \\ Department of Sociology and Anthropology, Bar-Ilan University, Ramat-Gan 5290002, Israel; \\ coopers@mail.biu.ac.il \\ * Correspondence: shlomoguzmen@gmail.com
}

Received: 29 October 2019; Accepted: 17 December 2019; Published: 21 December 2019

check for updates

\begin{abstract}
In recent years, theories of structuralism in anthropology are being re-examined. This article uses structural analysis to create an anthropological interpretation of the Joseph story in the Bible and to evaluate its modes of interpretation and how it influences the formation of Jewish religious practices. The structural interpretation shows how stories serve as models for the process of cultural creation. In the case of Joseph's story, the narrative creates a mythology but also a recurring operational infrastructure that echoes in different contexts: in ethical actions, in halachic perception, and in the foundation of various practices in Judaism including concealment and removal, covering and disrobing, that appear repeatedly and function as structures that signify and enable change.
\end{abstract}

Keywords: anthropology; structuralism; Judaism; the biblical Joseph; Scriptures; rituals; cultural change

\section{Introduction: Return to Structuralism and Its Place in the Holistic Interpretation of Jewish Cultures}

As is customary among anthropologists, we will begin with an anecdote from the field. In this case, two Jewish anthropologists who are engaged in the anthropology of Jews and Judaism. The field is, among other things, the neighborhood synagogue:

There was an elderly man in the shul (synagogue) who used to approach one of us at least once every week saying: "I have a simcha (a joyful family occasion) this week." The last time we spoke to him he said, "My grandson is making a halaka ${ }^{1}$ for my great-grandson. You see the number in my arm? We fucked them. Sure, I got a number on my arm, but my great-grandson is here and he is making a halaka and we're holding it now!" I said to him, "Do you know what you do with the hair from the halaka? Anthropologist Yoram Bilu (2003) says you give some of it to the mother and some of it to the grandmother. I have a lock of my hair that my parents saved from when I was three years old." He said, "No, no. The hair is going to stay with my grandson." I asked, "What is he going to do with it?" and the guy didn't know. But he thought for a minute and then he said, "He'll probably burn it with the chametz."

According to Leach and Aycock (1983), culture is a patchwork, but it is a patchwork where the patches work together, and the pieces come from whatever is available in the cultural surroundings. There is no Jewish custom whereby hair removed during the halaka ceremony is burned together with the chametz, the bread that remains on the morning before the Passover Seder. But the solution offered by the grandfather in the synagogue "makes sense" for him and for every Jew who is proficient in

1 Halaka (Arabic for haircut), the ritual cutting of the hair of a religious boy at the age of three. For an ethnographic description of the ceremony see (Bilu 2003). 
religious practice, because it fits with other Jewish practices. The grandfather was using the tool his culture provides in order to generate a new custom. As anthropologists, we identify these customs and try to understand them, but the person who creates them is the one who lives by and works with the culture.

In this article, we will discuss how the legend permeates thinking and shapes modes of cultural action. How it creates a recurring operational infrastructure that resonates in diverse contexts: in ethical actions, in halachic perception, in shaping various practices in Judaism, and in helping to create new religious rituals. We do so by harking back to a formative story and an old theory. The legend we will be dealing with is the definitive biblical story of Joseph, and the theory is the structuralist theory of anthropology.

In the early days of anthropology, they used to teach about culture (with a small c) and Culture (with a capital C). When we discussed Culture, we were referring to basic similarities. The anthropology we were engaged in dealt with the general concept of culture and how what we observed in different fields enabled us to better understand how culture works "as a thing" (Keesing and Strathern 1998). In the era of post-colonialism, and even earlier, in connection with Orientalism and the Crisis of Representation, this idea failed the test of essentialness. In other words, it turned culture into "a thing," something universal, in line with the philosophy of French anthropology, which was a kind of catholic or universal anthropology. When Lévi-Strauss wrote about a culture based on a model of France, it was "a big thing." When he wrote Tristes Tropiques (Lévi-Strauss 1961) for example, the Caduveo, Bororó, Nambikwara and the Tupi-Kawahib were for him all versions of the same process. When he (Lévi-Strauss 1975) discussed Paul Radin (1949) historical and particularistic description of "The Culture of the Winnebago: As Described by Themselves" in his seminal work: "Four Winnebago Myths: A Structural Sketch," he demonstrated (despite Radin's best efforts) how each one of these Big Myths of the Winnebago are basically a structural variation of the one before. As if it is all one.

We are no longer as concerned with inventing, revealing, or even discussing "universal cultural things" as was Lévi-Strauss (1968). What concerns us is the tools anthropology provides to deal with specific cultures, and how we might go about defining them.

Ironically, it is not inevitable that an anthropologist who acquired his or her education in a time and an environment in which academic discourse was immersed in fragmentation, hybridity, postmodernism, Orientalism and post-colonialism will develop an aversion to structuralist thought. The emphasis on synchronous, specific, behavioral and performance-based anthropological research virtually neutralizes the ability to imagine or think of structure, and accordingly, the thought of structure invokes fear. Fear of castles in the air. Fear that a vast distance separates it from theory that is anchored in the field. Nevertheless, it would appear that despite these misgivings, in recent years we are seeing renewed interest in structuralist theory and interpretation, or incorporating some of its elements in new theoretical trends (see, for example: Alexander and Smith 2001; Rutherford 2016; Thomassen 2009, 2016; Rothem and Fischer 2018). The application of structuralist theory is especially relevant in textual societies because it helps us understand how anthropologists and sociologists contend with the study of cultures that have iconic texts. Anthropologists and sociologists who engaged with iconic texts in the past were usually disciplinary experts, and it was rare to find scholars who also made an in-depth study of the cultural texts themselves. For religious scholars, this has always been a bone of contention as regards anthropologists. ${ }^{2}$ For the anthropologists, the text was but one item in a list of cultural items. For them, this was not knowledge acquired in childhood, nor were they familiar with the vast historical, mythical and practical context wherein the canonical text is set and within

2 For example, the criticism that was leveled at Mary Douglas (1966). Scholars of Judaism claimed that her lack of understanding of religious texts, in this case the Book Leviticus and its halachic commentary, led to the creation of her flawed theory. See for example the five articles dealing with the heritage and criticism in Purity and Danger by Hendel and Olyan (2008). Douglas accepted the criticism and reconsidered her claims in her preface to the Hebrew edition of Purity and Danger (published in 2002) with regard to the laws of kashrut in Leviticus. She admitted that she had erred in her earlier analysis. 
which it functions. Therefore, in the study of Jewish culture that we will deal with in this article, there was a large gap between the knowledge of Jewish scholars who were well-versed in the sources but did not know, or did not as a rule avail themselves of anthropological theory, and the anthropologists who had not acquired knowledge and had not developed tools that would allow them to examine Jewish canonical texts. ${ }^{3}$

Due to lack of space, this study will not delve into the well-known arguments about structural functionalism, but in regard to Jewish cultural systems and the ways in which Jews have created and interpreted halacha, it is not at all a bad idea to utilize this method. ${ }^{4}$

This paper is concerned with how cultures employ their own rules, how the anthropologist defines those rules, and how she or he discovers them. It becomes the task of the anthropologist to describe the tools of "the savages" and how they produce a new culture, using what Lévi-Strauss called "the work of the bricoleur" (construction by means of whatever materials are at hand), which is then applied by the anthropologists themselves using "the savages' ideas," to determine how it is used to provide local identity as well (Lévi-Strauss 1966). ${ }^{5}$

Our contention is that rituals, practices, and texts cannot be understood when examined in isolation. They must be included in the category of all practices of the same type, and instances of this practice must be examined in terms of the broad cultural aspects of the culture being studied. ${ }^{6}$ Once again, despite our yearning for a universal cultural theory, it is something we had to relinquish long ago.

\section{Method}

Structuralist analysis seeks to identify patterns, repetitions, and regularity as they are expressed in cultural content. This method of analysis calls for a holistic and integrative examination of the researched culture and makes it possible to draw comparisons between content appearing in texts, narratives, legends and myths, and the actions that are performed in rituals and everyday practices. This article uses primary structuralist analysis to locate and describe recurring patterns that emerge from the reading of the biblical Joseph story (Genesis chapters 37-50). Secondly, this method makes it possible to examine and analyze the emergence of parallel patterns in Jewish rituals, laws, and practices (for studies using structuralist analysis for the study of Judaism see, for example: Bilu 2003; Cooper 1986; Goldberg 1986; Rubin 2008, 2019; Silman 2013).

\section{The Story of Joseph as a Cultural Presentation}

As mentioned, this article will focus on the intersection of text and culture. We seek to understand the interface between culture and the text that culture produces. At the heart of this experience lies the question of what is the connection between the story or the cultural narrative and the texts in the Torah which are not narrative but laws and mitzvot (commandments), which the Sages also called halacha.

Jewish culture is first and foremost a halachic culture (Friedman 1991; Halbertal 1997; Dagan 2005; Ben-Raphael and Ben-Haim 2006), but there are extensive narrative passages in the Torah, including

3 For criticism of anthropologists' lack of familiarity with religious Jewish texts, see for example Goldberg (1986, 2003), who describes text as a constitutive element of Jewish culture, and the difficulties faced by anthropologists seeking to study Judaism as a textual society. For Judaism as a textual society, see also: (Silman 2013).

4 For the use of the structural theory to analyze Judaism, see for example the work of Cooper (1986) or the work of Silman (2013), who uses it to analyze the laws of Jewish halacha, or that of Levi (2009), who focuses on the curious parallels between structural theory and kabala-Jewish mysticism.

5 For the use of the term "the bricoleur" in contemporary Jewish settings, see (Werczberger 2017).

6 One of the few scholars who combined anthropological theory with profound knowledge of the Jewish religious text is Israeli sociologist and anthropologist Nissan Rubin. One of his key innovations is that he teaches what tools are needed to conduct such studies and what anthropology can possible contribute to historiographic research focusing on Judaism. Rubin's proficiency in the text, combined with anthropological sociological theories, has helped to establish a new avenue of research, which is clearly reflected in his works on the Jewish life cycle and the anthropology and sociology of the Talmud (see, for example, Rubin 2004, 2008, 2011, 2019). For more anthropological-sociological works dealing with how the religious text shapes Jewish culture, see, for example: (Heilman 1983; Friedman 1986; Goldberg 1986, 2003; Boyarin 1989, 1991; Soloveitchik 1994; El-Or 2002, 2006; Rubin 2008; Hakak 2012; Guzmen-Carmeli and Rubin 2014; Guzmen-Carmeli 2020). 
the long and significant narrative we will call Joseph's Story. This is a canonical text that has multiple existence, ${ }^{7}$ and as an accepted text (Boyarin 1989) it is included in the scope of the mythologies examined by Lévi-Strauss. Joseph's story is a story that is told over and over again. It is heard every year in the synagogue on the Sabbaths when the Torah portions Vayeshev, Miketz, Vayigash and Vayehi are read. The discourse on these Torah portions raises moral issues. They teach how one should act and how not to act. This forms the basis for a discussion about values and morals. We tell the story to our children in kindergarten and school, and also watch it in plays such as the musical staged in London, Broadway and Israel. ${ }^{8}$ It could therefore be argued that Joseph's story is in fact a cultural presentation (Schechner 2003; Lewis 2017) that informs the listener or viewer about his or her culture.

Structural interpretation is an accepted practice in Biblical studies (see for example Barr 1973; Greenstein 1999), including structural analysis of the Joseph story (see for example Alter 2011). However, this interpretation remains within the realm of the Biblical text itself.

By bringing an anthropological view to bear on this text, we would like to examine how Jewish society relates to "the ensemble of stories we tell ourselves about ourselves" (Geertz 1975, p. 452). ${ }^{9}$ Geertz claims that that familiar stories, such as in our case the story of Joseph, as well as sections of other familiar Torah narratives, are a tool for creating culture and cultural continuity. They create structures that resonate with other halachic and cultural processes over time. That is, they have an influence on the formulation of halacha and on the format of various Jewish practices. ${ }^{10}$

Let us dive into Joseph's story for a moment to illustrate some of the structure that recurs in the narrative. Of course, what is described below does not cover the whole story and its meanings, but rather attempts to bring to a new interpretation to the surface by means of the structuralist anthropological theory.

Like every narrative, the Biblical story of Joseph also contains repetitive patterns. As anthropologists, what interests us is not the repetitions of a particular subject as a storytelling element but rather the question of whether this theme provides inspiration. Does it create replicas which are used on an everyday basis, and is the structure expressed in the recurring theme significant in the process of creating new cultural practices?

The story of Joseph is spread over thirteen chapters in Genesis (chp. 37-50). It is the longest story in the Bible. We will summarize excerpts, with reference to a chapter that is not an integral part of the story, that of Judah and Tamar (chp. 38), which supposedly interrupts the narrative rhythm of the Joseph story, but is nevertheless an important element of the anthropological interpretation we propose here.

Joseph is a seventeen-year-old boy when he sets out to look for his brothers, who are tending their father's flock. This occurs after the Torah tells us that he told everyone who was willing to listen about his dreams, dreams of narcissistic pride wherein his older brothers and parents and even the sun and moon knelt and bowed down before him. It is important to note in this context that there is a dyad of two major dreams here: the dream of the sheaves and the dream of the stars, in which the brothers and their parents kneel and bow to him. We will further illustrate how the dyadic structure (Hsu 2017) is repeated throughout the story in other events, such as in the dream sequence, in order to emphasize a particular message: to create a "closed text" (Funkstein and Steinsaltz 1989; Funkstein 2001) that is not

7 Armstrong 1986. For multiple texts in a Jewish context, see (Guzmen-Carmeli 2020).

8 "Joseph and the Amazing Technicolor Dream Coat" by Tim Rice and Andrew Lloyd Weber premiered in the West End of London in 1973 and on Broadway in 1982. Different versions have repeatedly been staged. In Israel, it was first performed by third year students of the School of Performing Arts in October 2016.

9 If we borrow the overused formulation of Geertz, one of the most prominent proponents of the structuralist theory who was actually one of those who ultimately laid it to rest. In a wonderfully ironic twist, his seminal work on the classic Balinese Cock Fight received a structuralist analysis (Smith 2008), which aims to return to this theory, this time out of a desire to reconcile the theory and the one who originally buried it.

10 On the relationship between legend and halacha, see for example: Rosenak 2005; Rubin 2019, pp. 32-34). 
open to interpretation. In the other events, the dyad demonstrates the correction of a flaw or mistake that occurred in the first story.

Joseph encounters his brothers in Dotan. They see him from afar. Their anger has been simmering, so while he is still distant, they plan to kill him. Reuben saves his life by suggesting that they throw him into a pit, because he intends to restore him later to their father. The brothers accept Reuben's suggestion not to kill him. They strip him of his colorful striped coat and throw him into the pit. We would like to add another interpretation to the many traditional and modern interpretations of this passage. The striped coat was taken from Joseph and immersed in the blood of a slaughtered goat. This action resembles circumcision, in which the foreskin is cut, and the blood of the covenant is drawn. Rashi, according to Midrash Rabba, claims that the story is predictive or related to the selling of Joseph; that the word "stripes" (passim in Hebrew) at the beginning of the story can be read as an acronym for parts of the story that will occur later: Potiphar, merchants, Ishmaelites, Midianites (Potiphar, sochrim, Yishmaelim, Midianim). ${ }^{11}$ Judah persuades the brothers not to kill Joseph but to take him out of the pit and sell him to the Ishmaelites (Genesis 37:26-28). The Midianites sell Joseph to Potiphar, Pharaoh's chamberlain and chief steward. As we know, Joseph's descent into the pit and his removal from it, his being clothed in the garment and being stripped of it, will recur later in the story.

The continuity of the narrative is ostensibly interrupted by another story, that of Judah and Tamar (chp. 38), which actually exemplifies the conceptual infrastructure we are dealing with. ${ }^{12}$ At the beginning of chp. 38, Judah's marriage to the daughter of Shua the Canaanite is described, followed by the birth of his three sons: Er, Onan, and Shela. Er, the firstborn of Judah, takes Tamar as his wife. And the scripture says, "But Er, Judah's firstborn, was displeasing to the Lord, and the Lord took his life" (38:7). Later in the section, we learn for the first time about the commandment of yibum. Onan, Er's younger brother, is asked to take Tamar in levirate marriage but avoids doing so (as his name graphically indicates). ${ }^{13}$ Of him, too, it is written, "What he did was displeasing to the Lord" (38:10). Although the text makes it clear that Tamar was not to blame for the death of Judah's sons, he feared that she was a "deadly woman" and he was not prepared to marry her to his youngest son Shela. In order not to be seen openly flouting the laws of kinship, he asks her to wait for Shela to grow up. Tamar waits for Shela but time passes and Shela is not given to her, so she decides to act on her own. This leads to a further incidence of covering up: "She took off her widow's garb, covered her face with a veil" (38:14). The wording parallels Rebecca's act of covering herself when she first saw Isaac from afar: "She took her veil and covered herself" (Genesis 24:65). By means of this parallel, the text is hinting that despite the problematic conduct of Tamar, it is precisely what she should have done given her situation. In light of the fact that Judah and his sons have flouted the kinship laws, she is seeking to preserve them by seducing Judah and bearing a child from his seed.

After seducing Judah, who believed her to be a prostitute, Tamar returns home. He leaves his seal, his threads, and his staff with her as surety. Some commentators interpret 'thread' as the cord to which his seal was attached, ${ }^{14}$ but since this is apparently not significant, it is unclear why Tamar wanted it and why the scriptures even mention it. However, according to Targum Onkelos and Rashi's interpretation, ${ }^{15}$ the thread is a garment, and Rashbam says it refers to an area, in other words, a belt. ${ }^{16}$ In the story, her covering saves Tamar when Judah recognizes the seal, thread and staff as belonging to him. So, at least according to some interpretations, the removal of the seal and the threads is a

11 Rashi on Genesis 37:3: "A midrashic legend based on his troubles, for he was sold to Potiphar and to merchants and to Ishmaelites and to Midianites." According to Bereshit Rabbah 84:3-4.

12 See also Alter (2011) interpretation. He suggests a structural aspect to this chapter, claiming that the story of Judah and Tamar is not an unconnected addition that disrupts the order of the story, but it constitutes an integral, direct part of the narrative of Joseph's story.

13 Onan is Hebrew for masturbation.

14 For example, the translation attributed to Jonathan.

15 Rashi (Targum Onkelos): The ring which serves as your seal, and your garment with which you cover yourself.

16 Ramban interpreted it as a head covering or neckerchief. Radak interpreted it as a garment or scarf. 
continuation of the code of exposure and coverage that recurs throughout the Tamar and Judah story and the Joseph story. The Tamar and Judah concealment dyad is a clue to the identity of those who are covered. Through concealment, Tamar reminds Judah that she is a part of him; the covering is a reminder of collective identity.

After the death of his two older sons, his wife also died. In the description of Judah's first family, another dyad is revealed which teaches us a progression of restoration and repair of the kinship system. The Canaanite descendants of Judah, Er, and Onan are dead. Shela, his youngest son, is marginalized in the kinship system. In contrast, Peretz and Zerah, Judah's sons, born to his second family as a result of the encounter with Tamar, are incorporated into the kinship system and Peretz becomes the father of the Davidic dynasty.

The story of the birth of the twins also creates a dyad. This story "corrects" the similar story of the birth of Jacob and Esau (Genesis 20:24-26). Peretz "corrects" it by succeeding to be born first, whereas Jacob failed to do so and was born holding Esau's heel. Zerah, Peretz's twin, also effects a "correction" by remaining within the kinship system of the tribe of Judah, whereas Esau was rejected from the kinship system of the Jewish people. The story of Judah and Tamar deliberately interrupts the narrative of the Joseph story: it implies that there are rules and creative tools for restoring and repairing the social structure, and these rules are also reflected in Joseph's story.

In this context, it should be noted that covering and concealment also feature in the story of Jacob and Esau: "Rebecca then took the best clothes of her older son Esau, which were there in the house, and had her younger son Jacob put them on; and she covered his hands and the hairless part of his neck with the skins of the kids" (Genesis 27:15-16). Rebecca gives Jacob Esau's festive clothes and instructs him to cover his hands and neck with the goatskins so that he resembles his hairy brother. This cover signifies a deviation from the norm, entering a liminal state. The removal of the covering marks a return to routine after the situation is corrected. As with the Tamar and Judah story, Jacob also deviates from the accepted laws of kinship in order to preserve it. This deviation is presented as a praiseworthy act, given the circumstances. Thus, we are repeatedly shown what is normative, but at the same time we are shown how culture can accept changes and deviations from the norm.

After his descent to Egypt, Joseph is purchased by Potiphar, Pharaoh's chamberlain and chief steward (Genesis 39:1). He succeeds in his work and is well-liked, especially by Potiphar's wife who tries to seduce him (Genesis 39:2-20). Here, too, we see the pattern of coverage and disclosure: "She caught hold of him by his garment and said, "Lie with me!" But he left his garment in her hand and got away and fled outside" (Genesis 39:12). Potiphar's wife takes his garment to prove something false, just as the brothers took Joseph's garment.

Once again Joseph descends, this time to another pit, the prison (Genesis 40:1-23). There, too, he is successful and becomes the chief jailer's assistant. He later interprets another dream dyad. This time it is not his own dreams, but those of the chief cupbearer and the chief baker. The chief cupbearer receives a pardon from Pharaoh and leaves the prison, but he forgets Joseph. However, he will remember him later when a dream dyad of Pharaoh needs interpreting. Then Joseph is brought up again from the pit: "Then Pharaoh sent for Joseph, and he was rushed from the dungeon. He had his hair cut and changed his clothes, and he appeared before Pharaoh" (Genesis 41:14). The act of dressing and removal will also be repeated later in the story when Joseph is put in charge of all the land of Egypt, through an act of removing and adding. Pharaoh removes his ring, gives it to Joseph, and dresses him in royal clothes.

Later in the story, a further incidence of discovery and coverage occurs. The brothers rend their garments when Joseph's goblet is found in Benjamin's bag (Genesis 44:1-13). And finally, at the end of the story, when Joseph is revealed to the brothers, he sends them on their way with many gifts: "To each of them he gave a change of clothing but to Benjamin he gave three hundred pieces of silver and five changes of clothing" (Genesis 45:22). The text specifically notes that he gave Benjamin five changes of clothing.

The question is: Why this repetition of discovery and covering, of wrapping and removal? Why is the issue of clothing so significant? The act of wrapping and disrobing will become clearer after holistic 
analysis and after we perceive that it resonates in different configurations in other cases. Joseph's story seems to be a model of action (Douglas 1996). Wrapping and disrobing or covering and removal plays a leading role in many Jewish rituals and Jewish practices.

\section{Covering and Removing, Wrapping and Disrobing as Structures of Preservation and Change}

Law professor Robert Cover emphasizes how narrative translates into law:

"For every constitution there is an epic, for each decalogue a scripture. Once understood in the context of the narratives that give it meaning, law becomes not merely a system of rules to be observed, but a world in which we live." (Cover 1983, pp. 4-5)

Cover is referring to the manner in which laws are formed, but his remarks also hold true for cultural customs and practices. Like the law, they reflect a certain cultural context that integrates past and present, traditional narrative and contemporary reality.

Narratives, myths, and Legends do not remain in the province of the amorphous text, it is not just a story we know and tell over and over, but it appears repeatedly in changing contexts. The idea of covering or removing as a structure that indicates and allows for change is not specified in halacha. On the contrary, it derives its power from the fact that it resonates in the culture without being said. Legend or myth permeates thinking, shapes modes of cultural conduct, and creates what anthropologist Francis L.K. Hsu (2017), whose work in psychological anthropology has once again justifiably become important in recent years, called "the grammar of culture." This refers to the recurring patterns that characterize the system and outline possible avenues of action in a particular culture. These avenues draw inspiration from the wider cultural system and reinforce the importance of the narrative, clarifying its role not only as establishing a joint narrative and values, but also as a tool for formulating cultural conduct.

In describing the structural tendency of cultural systems, Lévi-Strauss used the distinction of basic dichotomies (nature/culture; man/woman; we/they and so on). Dealing with them creates cultural phenomena ranging from myths to kinship structures and more, but another aspect of his structural theory was somewhat neglected; that is the reference to repetition which appears in the modes of cultural expression, in the creation of stories, customs and practices. To explain the repetition and similarity between different practices, Lévi-Strauss borrowed the musical term "Ouverture" (French: Opening), which is the instrumental introduction to a musical work that recurs in different styles and expansions throughout the work and becomes part of the recording. Correspondingly, the cultural overture that Lévi-Strauss describes is the repetition of a familiar structure that appears, for example, as a tool for the creation of "absorbable cultural practices", that is, customs that are immediately identified as an integral part and a natural continuation of the cultural system (Lévi-Strauss 1969, 1978).

According to this interpretation, it is not surprising to discover the structure of covering and uncovering in Jewish halacha, custom and folklore. The repetition of a particular pattern of action in the canonical text in different configurations and contexts helps to shape practices, because it creates a way of thinking about culture, performing it, and producing new cultural expansions. In the case under discussion, these are actions that seek to signal change.

We will briefly review some occurrences of coverage and concealment, or wrapping and disclosing, in various Jewish practices. Readers who are familiar with traditional Judaism can probably add examples of their own.

The first "removal" in the Bible is that of the foreskin at the circumcision ceremony. The word has been described (see Cooper 1986; Bilu 2003) as an action that marks the male newborn's transition from the natural, dangerous and destabilized state of his earliest days, when he is physically vulnerable, still lacking identity, and he is not yet a member of the community. Only through circumcision is his identity determined by his entry into the chain of generations: "And his name shall be called in Israel, so-and-so son of so-and-so," says the celebrant who utters the circumcision blessing. By this spoken act (Austin 1975), his identity is formed: his first name, his affiliation with the Jewish people, 
and the explicit indication of who his father is (Rubin 1995, pp. 16-17; 28-29; see also Douglas 2002). The ceremony that finalizes his affiliation to the community occurs at the age of three where another removal is performed: the "halaka," the ceremony of shaving his head. ${ }^{17}$ Circumcision is the first ritual in the dyad of ceremonies that marks the newborn as one who is destined for the world of words, in other words, the study of Torah. But after circumcision, he returns to the women's world to be cared for by his mother and sisters. The second ritual, the halaka, repairs the failings of the circumcision ceremony. Through another removal, this time of the hair on his head, he is removed from the world of women to the world of men. The natural hair that grows untamed is linked in kabalistic literature to severe judgment. It is cut until only the side-locks remain, as a clear physical cultural expression. The halaka is performed at the age when memory begins and, at the same time, the child enters the "heder" to begin learning Torah (Bilu 2003; Marcus 1998; Baumgarten 2005; see also Rubin 1995, pp. 17-19).

The term orla (foreskin) has also been linked to more abstract discussions about removals that allow for change. Six types of "foreskins" are mentioned in the Bible: of the flesh (Genesis 17:1), the lips (Exodus 6:12), the ear (Jeremiah 6:10), and the heart (Jeremiah 9:25). For the first three years after planting, the fruit of a tree is also called orla (Leviticus 19:23), and gentiles, too, are referred to as arelim (Habakkuk 2:16). Rashi (Exodus 6:12, in his commentary that begins "arel sfata'im" (impeded speech)) explains: "Arel sfata'im—sealed of lips. Of any impeded speech, I say that it is sealed." It is the sealing of a physical thing that hides the wholeness of the real thing, or it hides a spiritual defect that manifests itself in the lack of contact with God. Foreskins, or coverings, whether spiritual or tangible, are additions. Therefore, cultural logic demands that they be removed. In this way, removal is required not only of the orla of fruit, but of any food that is to be eaten by a Jew. The way to turn "non-Jewish food" into "Jewish food" is by removing part of it: "offer the first fruits and vegetables" (Exodus 23:19; 34:26; Deuteronomy 26:1-11); the harvest must be tithed (Numbers 18:12); a portion of bread dough must be set aside (Numbers 16:17-21); for three years, the fruit of a tree must be set aside (Leviticus 19:23). Like the harvest, wine, oil, cattle and sheep must be tithed (Leviticus 27:30-32)" (Rubin 1995, p. 16).

Another instance of the practice of cutting and removing, which renders food permissible to Jews, is to be found in the laws for making beef, mutton, poultry, and fish kosher. First, the animals are classified as kosher or non-kosher for eating, according to signs of purity and impurity. Second, ritual slaughter is required to render them kosher (except for fish). Third, all blood must be removed (except for fish) by soaking and salting; the tendon of the thigh must be removed by puncturing the tendon; and other internal organs and certain fats must be removed. Only then does the food change its nature and become kosher. ${ }^{18}$

Removal is also a feature of the sacrifices offered in the Temple, something which is discussed extensively in the Bible (see, for example, Exodus 13, Leviticus 1, Numbers 18). After slaughter, the parts that cannot be used are removed. Thus, the liver and certain fats are removed, which alters the sacrifice from a natural state-bleeding flesh—to a state of holiness, by burning it on the altar, as a sacrifice to God.

Another practice is challah, the setting aside of a portion of bread dough. This practice has gained strength in recent years as a women's ceremony. Challah is one of the three main strictures that the Sages imposed on women: nida, challah, and candle lighting on Shabbat evening (Mishnah, Shabbat 2:6). It refers to the portion of the dough that is dedicated to the priest. ${ }^{19}$ In recent years, it has come to occupy a religious-feminine space as a ritual linked to healing and abundance (Neriya-Ben Shahar 2014). The challah ceremony, too, has a dyadic structure and it is done twice: the separation of the requisite tithes from the flour, and the separation of the challah portion from the dough itself. Before the separation ritual, the flour and water are kneaded into dough, which involves a natural process of

17 The halaka is a relatively new custom. It is first mentioned by the early aharonim in the responsa of Rabbi David Ben Zimra (Spain 1479-Safed 1573), as a popular custom of cutting hair at the grave of the prophet Samuel.

18 See also (Rubin 2019, pp. 242-43).

19 See Numbers 15:18-21. 
fermentation. This is a liminal process over which one has no control. The anomalous, uncontrolled state is regulated with the help of challah. To regain control, natural fermentation is accompanied by a religious ritual that serves as a platform for abundance and health for participants in the ceremony. The ceremony concludes with the baking of the dough, thus eliminating the natural fermentation process and restoring control to the situation. ${ }^{20}$

Additional practices of covering, discovery and removal are also found in the ritual cycle of Jewish life. In the marriage ceremony, a veil covers the bride's face under the canopy and is removed at the end of the ceremony; the groom breaks the glass under the marriage canopy; the Shabbat loaves are covered during Friday night kiddush and afterwards they are uncovered. And there are the mourning rituals: tearing the lapels of the immediate relatives; covering the dead with a tallit and its removal or disqualification before burial. Indeed, covering and disclosure, wrapping and removal crop up repeatedly in ceremonial practices. Their incorporation marks transitions and corrections: from the natural to the cultural, from uncircumcised to childhood, from single to married, from life to death, from non-kosher to kosher. ${ }^{21}$

By means of halachot and practices, we have demonstrated how structure, in various configurations, repeatedly emerges and reverberates in culture. Through structure, changes can be made in the identity of material things, for example, from kosher to non-kosher. On the personal level, the newborn is given identity or culture and his designated role is clarified at his halaka. The removal that changes his appearance changes his identity and thus a new cultural state is created. The permanent configurations of Jewish culture of discovery and covering, wrapping and removal that indicate transition, allow for processes of change.

\section{Conclusions}

In this article, we discussed some of the intricacies involved in the ethnographical evaluation of textual culture. Such ethnography demands familiarity with the texts and their modes of interpretation and familiarity with the various cultural practices. Knowledge of the culture under study, combined with a focused and specific view, reveals the cultural "ouverture" and helps us understand how cultural choices are made. We can even say that something of the anthropologists' naiveté is lost when they understand the work of the bricoleur, as in the case where we dealt with the interface between the individual, the text, the culture in which it operates, and its structural aspect. it is important to note that in our use of structuralism; we do not offer a theory of causality, only a theory of availability. The assertion that we are influenced by structures does not eliminate the power of the individual to choose how to respond to a particular situation, but there is a cultural repertoire (Swidler 1986), and in our response to a particular event we pull out of the "toolbox" (Ortner 1973) the cultural tool that is appropriate to our circumstances. If there are various repetitions on a particular theme, we tend to choose it over others.

In Jewish culture, the textual component holds sway, providing, among other things, the means for coping with change. The result is a flexible culture. The text is a cultural field on which major problems are presented, while the solutions described in the text inspire ways to create various laws and customs. Moreover, with the help of holistic anthropological interpretation that places the emphasis not only on the specific case study but also on the broader context of the story and how it is embedded within the cultural system, the researcher succeeds in creating a new interpretation. In Joseph's story, it reveals the significance of the structure, the "ouverture," expressed in the story.

At the basic level, Joseph's story merges with a series of genealogical stories in Genesis and the Bible that describe the formation of the system of Hebrew kinship, the customary patterns of

20 For the process of wine fermentation as an uncontrollable condition and its place in liminal conditions, see (Silman 2013). Bread and wine are some of the basic symbols of Jewish transition ceremonies.

21 On transition ceremonies and correction ceremonies in Judaism, see (Rubin 1995, pp. 28-29). 
kinship, but also the manner of their violation. Joseph, like Tamar, demonstrates a situation in which the accepted pattern must be deviated from in order to preserve the family. Tamar must preserve Judah's family and Joseph must preserve the house of Jacob. The story that illustrates the rules of the kinship system and the rules of its infringement also illustrates moments when culture does not meet needs. At such times, it becomes necessary to unravel and reweave the existing norms. When we simultaneously present the narrative of Joseph's story and cultural practices, the cultural code becomes clearer and reveals the way in which the cultural text not only determines morality and halacha, but also creates diverse tools for change and cultural creation. Joseph's story challenges the cultural process by challenging the kinship system, both confirming it and presenting its modes of change. ${ }^{22}$

At a more abstract level of generalization, we can argue that the cultural situation is unformulated. The rules governing when to remove or when to cover are part of the power of culture. Anthropologist Alfred Kroeber (1952) taught us how culture reproduces itself. Culture "works" through structures and by means of these structures people have the ability to create, consciously or unconsciously, creative tools for change that do not deviate from the boundaries of the cultural system. Lévi-Strauss continues this thinking when he makes a distinction between the bricoleur and the engineer (Lévi-Strauss 1966). The bricoleur carries out the work of assembly and renewal by using materials that exist in the culture. The stories in the case we dealt with are the existing materials. They are available for cultural elaboration and they illustrate the process of halachic creation, the practices, the deviations, and the way in which they are corrected. The argument that clearly emerges from Rubin $(1997,2004,2008,2019)$ works, which formed an important basis for our discussion and the link we seek to make between structuralist theory and the interpretation of religious Jewish texts and practices, is that rituals, practices, and texts cannot be understood when explored in isolation. They must be included in all practices of the same type, and the instances of this practice must be examined beyond ritual and practice, in the light of the broader cultural aspects. In the case of Joseph's story, the narrative creates a mythology but also an infrastructure for action that resonates in different contexts as an ethical practice, in the perception of the concept of halacha, and in the formation of various practices.

Author Contributions: Equal contribution. All authors have read and agreed to the published version of the manuscript.

Funding: This research received no external funding.

Conflicts of Interest: The authors declare no conflict of interest.

\section{References}

Alexander, Jeffrey, and Alexander Philip Smith. 2001. The Strong Program in Cultural Theory: Elements of a Structural Hermeneutics. In Handbook of Sociological Theory. Boston: Springer, pp. 135-50.

Alter, Robert. 2011. The Art of Biblical Narrative. New York: Basic Books.

Armstrong, Paul B. 1986. The Multiple Existence of a Literary Work. The Journal of Aesthetics and Art Criticism 44: 321-29. [CrossRef]

Austin, John L. 1975. How to Do Things with Words. Oxford: Oxford University Press.

Barr, James. 1973. Reading the Bible as literature. Bulletin of the John Rylands Library 56: 10-33. [CrossRef]

Baumgarten, Elisheva. 2005. Mothers and Children: Family Life in Ashkenaz in the Middle Ages. Jerusalem: Zalman Shazar Center. (In Hebrew)

Ben-Raphael, Eliezer, and Lior Ben-Haim. 2006. Contemporary Jewish Identities: Are We Still “One Jewish Nation"? Iyunim Bitkumat Israel 16: 463-97. (In Hebrew).

Bilu, Yoram. 2003. From Milah (Circumcision) to Milah (Word): Male Identity and Rituals of Childhood in the Jewish Ultraorthodox Community. Ethos 32: 172-203. [CrossRef]

22 A further challenge will be described later on, when Joseph plans and acts to forestall natural dangers, by establishing storehouses to weaken entropy, to overcome the drought, the dangerous lack of balance. 
Boyarin, Jonathan. 1989. Voices around the Text: The Ethnography of Reading at Mesivta Tifereth Jerusalem. Cultural Anthropology 4: 339-421. [CrossRef]

Boyarin, Jonathan. 1991. Jewish Ethnography and the Question of the Book. Anthropological Quarterly 64: 14-29. [CrossRef]

Cooper, Samuel. 1986. The Laws of Mixture: An Anthropological Study in Halakhah. In Judaism Viewed from Within and from Without: Anthropological Studies. Edited by Harvey E. Goldberg. New York: State University of New York Press, pp. 55-74.

Cover, Robert M. 1983. The Supreme Court, 1982 Term-Foreword: Nomos and Narrative. Harvard Lew Review 97: 4-68.

Dagan, Hagai. 2005. Judaisms, a Collective Picture. Tel Aviv: Map and Tel Aviv University. (In Hebrew)

Douglas, Mary. 1996. Natural Symbols: Explorations in Cosmology. New York: Pantheon. First published 1970.

Douglas, Mary. 2002. Implicit Meanings: Selected Essays in Anthropology. London: Routledge. First published 1975.

Douglas, Mary. 1966. Purity and Danger. London: Routledge, Hebrew Translation Appeared in 2002. Tel Aviv: Resling.

El-Or, Tamar. 2002. Next Year I Will Know More: Identity and Literacy Among Young Orthodox Women in Israel. Detroit: Wayne State University Press.

El-Or, Tamar. 2006. Reserved Seats: Gender Ethnicity and Religion in Contemporary Israel. Tel Aviv: Am Oved. (In Hebrew)

Friedman, Menachem. 1986. Life and Book Tradition in UltraOrthodox Judaism. In Judaism Viewed from Within and from Without: Anthropological Studies. Edited by Harvey Goldberg. Albany: State University of New York Press, pp. 235-55.

Friedman, Menachem. 1991. Haredi Society—Sources, Trends, and Processes. Jerusalem: Jerusalem Institute for Israel Research. (In Hebrew)

Funkstein, Amos. 2001. Knowledge as the Key to Salvation. Zmanim 13: 4-9. (In Hebrew).

Funkstein, Amos, and Adin Steinsaltz. 1989. Sociology of Ignorance; Tel Aviv: Ministry of Defense. (In Hebrew)

Geertz, Clifford. 1975. The Interpretation of Culture. London: Hutchinson.

Goldberg, Harvey E., ed. 1986. Judaism Viewed from within and from without, Anthropological Studies. New York: SUNY Press.

Goldberg, Harvey E. 2003. Jewish Passages: Cycles of Jewish Life. Berkeley: University of California Press.

Greenstein, Edward L. 1999. Reading strategies and the story of Ruth. In Women in the Hebrew Bible: A Reader. Edited by Bach Alice. New York: Routledge, pp. 211-31.

Guzmen-Carmeli, Shlomo. 2020. Encounters around the Text, Ethnography of Judaisms. Haifa: Haifa University Press and Pardes Publishing, forthcoming. (In Hebrew)

Guzmen-Carmeli, Shlomo, and Nissan Rubin. 2014. 'Tikkun' (Divine Repair) and Healing in a Kabbalistic Yeshiva: Using Sacred Texts as Instrumental Devices. Contemporary Jewry 34: 217-41. [CrossRef]

Hakak, Yohai. 2012. Young Men in Israeli Haredi Yeshiva Education: The Scholars Enclave in Unrest. Leiden: Brill.

Halbertal, Moshe. 1997. People of the Book: Canon, Meaning, and Authority. Cambridge: Harvard University Press.

Heilman, Samuel C. 1983. The People of the Book: Drama. Fellowship, and Religion. Chicago: Chicago University Press.

Hendel, Ronald, and Saul M. Olyan. 2008. Beyond Purity and Danger: Mary Douglas and the Hebrew Bible. The Journal of Hebrew Scriptures 8: 2-4. [CrossRef]

Hsu, Francis L. K. 2017. Kinship and Culture. New York: Routledge.

Keesing, Roger, and Andrew Strathern. 1998. Cultural Anthropology. A Contemporary Perspective. Belmont: Wadsworth Publishing.

Kroeber, Alfred L. 1952. The Nature of Culture. Chicago: University of Chicago Press.

Leach, Edmund, and D. Alan Aycock. 1983. Structuralist Interpretations of Biblical Myth. Cambridge: Cambridge University Press.

Levi, Jerome M. 2009. Structuralism and Kabbalah: Sciences of Mysticism or Mystifications of Science? Anthropological Quarterly 82: 929-84. [CrossRef]

Lévi-Strauss, Claude. 1961. A World on the Wane. New York: Criterion Books.

Lévi-Strauss, Claude. 1966. The Savage Mind. Chicago: University of Chicago Press.

Lévi-Strauss, Claude. 1968. Structural Anthropology. London: Penguin.

Lévi-Strauss, Claude. 1969. The Raw and the Cooked: Introduction to a Science of Mythology (Vol. 1). New York: Harper and Row. 
Lévi-Strauss, Claude. 1975. Four Winnebago Myths: A Structural Sketch. In The Human Experience. Edited by David H. Spain. Los Angeles: Homewood, pp. 351-61.

Lévi-Strauss, Claude. 1978. Myth and Meaning. Toronto: University of Toronto Press.

Lewis, Ioan. 2017. Social and Cultural Anthropology in Perspective: Their Relevance in the Modern World. New York: Routledge.

Marcus, Ivan G. 1998. Rituals of Childhood: Jewish Acculturation in Medieval Europe. New Haven: Yale University Press.

Neriya-Ben Shahar, Rivka. 2014. Women's Strategies in Creating and Renewing Religious Rituals. Iyunim Bitkumat Israel 24: 258-82. (In Hebrew).

Ortner, Sherry B. 1973. On Key Symbols. American Anthropologist 75: 1338-46. [CrossRef]

Radin, Paul. 1949. The Culture of the Winnebago: As Described by Themselves. Baltimore: Waverly Press.

Rosenak, Avinoam. 2005. Legends and Halacha: Reflections on Trends in Thought and Philosophical Research on Halacha. In Journey to Halacha: Interdisciplinary Studies in the World of Jewish Law. Edited by Amichai Berholtz. Tel Aviv: Yediot Haharonot, pp. 285-312. (In Hebrew)

Rothem, Nitzan, and Shlomo Fischer. 2018. Reclaiming Arnold Van Gennep's Les rites de passage (1909): The Structure of Openness and the Openness of Structure. Journal of Classical Sociology 18: 255-65. [CrossRef]

Rubin, Nissan. 1995. The Onset of Life: Birth, Circumcision, and Pidyon HaBen Ceremonies According to the Sages. Tel Aviv: Hakibbutz Hameuhad. (In Hebrew)

Rubin, Nissan. 1997. The End of Life: Burial Ceremonies According to the Sages. Tel Aviv: Hakibbutz Hameuhad. (In Hebrew)

Rubin, Nissan. 2004. The Joy of Life: Betrothal and Marriage Ceremonies According to the Sages. Tel Aviv: Hakibbutz Hameuhad. (In Hebrew)

Rubin, Nissan. 2008. Time and Life Cycle in Talmud and Midrash: Socio-Anthropological Perspectives. Boston: Academic Studies Press.

Rubin, Nissan. 2011. Sociological-Anthropological Theories for the Interpretation of Texts. In Halacha, Meta-Halacha, and Philosophy. Edited by Avinoam Roznik. Jerusalem: Van Leer Institute, pp. 98-121. (In Hebrew)

Rubin, Nissan. 2019. Bending Frameworks: Processes of Change in the Traditions of the Sages. Jerusalem and Bnei Brak: Hakibbutz Hameuhad. (In Hebrew)

Rutherford, Danilyn. 2016. How Structuralism Matters. HAU: Journal of Ethnographic Theory 6: 61-77. [CrossRef] Schechner, Richard. 2003. Performance Theory. New York: Routledge.

Silman, Naomi. 2013. The Symbolic Significance of Wine in Jewish Culture. Tel Aviv: Hakibbutz Hameuhad, Sifriyat Hillel ben Haim. (In Hebrew)

Smith, Philip. 2008. The Balinese Cockfight Decoded: Reflections on Geertz, the Strong Program and Structuralism. Cultural Sociology 2: 169-86. [CrossRef]

Soloveitchik, Haym. 1994. Rupture and Reconstruction: The Transformation of Contemporary Jewry. Tradition 28: 64-131.

Swidler, Ann. 1986. Culture in Action: Symbols and Strategies. American Sociological Revieww 51: 273-86. [CrossRef] Thomassen, Bjørn. 2009. The Uses and Meanings of Liminality. International Political Anthropology 2: 5-27.

Thomassen, Bjørn. 2016. Liminality and the Modern: Living through the In-Between. London and New York: Routledge. Werczberger, Rachel. 2017. Jews in the Age of Authenticity: Jewish Spiritual Renewal in Israel. Bern: Peter Lang.

(C) 2019 by the authors. Licensee MDPI, Basel, Switzerland. This article is an open access article distributed under the terms and conditions of the Creative Commons Attribution (CC BY) license (http://creativecommons.org/licenses/by/4.0/). 